\title{
Awareness about Liver Cancer in Biotechnology Students
}

\author{
Muhammad Imran Qadir* and Sidra Noureen \\ Institute of Molecular Biology and Biotechnology, Bahauddin Zakariya University, Pakistan
}

*Corresponding author: Muhammad Imran Qadir, Institute of Molecular Biology and Biotechnology, Bahauddin Zakariya University, Multan, Pakistan

Submission: 眥 April 12, 2018; Published: 些 May 29, 2018

\begin{abstract}
Liver cancer is a major disease caused by sudden mutation occurred in the genes. To cure this disease gemcitabine seems to be affective. Gemcitabine is anticancer agent that has profile containing mild toxicity. It seems to be affective in solid tumors. To check its effectiveness, a questionnaire was developed and the awareness about liver cancer is checked in the post graduate students. All the students were fully aware of this disease.

Keywords: Liver cancer; Mutation; Gemcitabine; Treatment; Effectiveness
\end{abstract}

\section{Introduction}

The liver plays a vital role in metabolism of nutrients and various antibiotics, like food additives, drugs and environmental pollutants. It is largest gland in the human body. The important processes are associated with regulation of the carbohydrate, lipid, amino acid and the hormone metabolism. Gemcitabine has been associated with important thrombotic and vascular side effects. Its use is being wider in different fields Dasanu [1].

Gemcitabine is used in the chemotherapeutic treatment Patients respond to it but sometimes give a very poor response. Gemcitabine is a new anticancer agent with a mild toxicity profile, which has major activity in many solid tumors. Therefore we investigated the effect of gemcitabine in patients with different methods Kubicka et al. [2]. It forms complex with the SWI/SNF

and helps the cells to enter senescence. Senescence is a stage in which the cells can no longer divide and proliferation of cells stops. Gemcitabine dose will be given on daily basis two times a day to check its effect on the arid1b gene liver cancer. Gemcitabine is a cytotoxic cytidine analog, which is widely used in anti-cancer therapy. D'Costa et al. [3]. The basic purpose of this study was to provide the awareness of university students about the disease.

\section{Methodology}

This questionnaire was developed to check the awareness of students about the liver cancer.39 students was selected from BZU, the inclusion criteria was M.Phil. Student and exclusion criteria were that they were not the students of BS (Table 1).
Table 1: Questionnaire to evaluate awareness about etiology of liver cancer.

\begin{tabular}{|c|c|c|}
\hline Liver cancer & Yes & No \\
\hline \multicolumn{3}{|l|}{ Viral disease } \\
\hline \multicolumn{3}{|l|}{ Bacterial disease } \\
\hline \multicolumn{3}{|l|}{ Fungal disease } \\
\hline \multicolumn{3}{|l|}{ Genetic disease } \\
\hline \multicolumn{3}{|l|}{ Metabolic disease } \\
\hline \multicolumn{3}{|l|}{ Ever suffered from liver cancer } \\
\hline \multicolumn{3}{|l|}{ You } \\
\hline \multicolumn{3}{|l|}{ Your family } \\
\hline \multicolumn{3}{|l|}{ Your relative } \\
\hline \multicolumn{3}{|l|}{ Your neighbor } \\
\hline \multicolumn{3}{|l|}{ Your friend } \\
\hline \multicolumn{3}{|l|}{ Liver cancer transmitted by } \\
\hline \multicolumn{3}{|l|}{ Contacts or blood transfusion } \\
\hline \multicolumn{3}{|l|}{ From parents to offspring } \\
\hline \multicolumn{3}{|l|}{ Liver cancer may be treated by } \\
\hline \multicolumn{3}{|l|}{ Medicines } \\
\hline \multicolumn{3}{|l|}{ Surgery } \\
\hline Do not worry, it is easily curable & & \\
\hline
\end{tabular}




\section{Results}

Awareness about etiology of liver cancer is given in table 2. The ratio of results varies among male and female students. It shows that $76 \%$ of the male and female said that it is a viral disease and
$24 \%$ says it's not. While $18 \%$ said that it's a bacterial disease and $82 \%$ said it's not. $5 \%$ said that it's a fungal disease while $95 \%$ said it's not. Genetic disease ratio varies among them as 55\% and $45 \%$. $76 \%$ of them said as it's a metabolic disease while $24 \%$ said it's not (Table 2).

Table 2: Awareness about etiology of liver cancer: Views of Postgraduate Biology Students.

\begin{tabular}{|c|c|c|c|c|c|c|}
\hline \multirow{2}{*}{ Questions } & \multicolumn{2}{|c|}{ Male } & \multicolumn{2}{|c|}{ Female } & \multicolumn{2}{|c|}{ Total } \\
\hline & Yes & No & Yes & No & Yes & No \\
\hline Viral disease & $83 \%$ & $17 \%$ & $75 \%$ & $25 \%$ & $76 \%$ & $24 \%$ \\
\hline Bacterial disease & $0 \%$ & $100 \%$ & $21 \%$ & $79 \%$ & $18 \%$ & $82 \%$ \\
\hline Fungal disease & $0 \%$ & $100 \%$ & $06 \%$ & $94 \%$ & $05 \%$ & $95 \%$ \\
\hline Genetic disease & $17 \%$ & $83 \%$ & $62 \%$ & $38 \%$ & $55 \%$ & $45 \%$ \\
\hline Metabolic disease & $50 \%$ & $50 \%$ & $81 \%$ & $19 \%$ & $76 \%$ & $24 \%$ \\
\hline \multicolumn{7}{|c|}{ Ever suffered from liver cancer } \\
\hline You & $0 \%$ & $100 \%$ & $0 \%$ & $100 \%$ & $0 \%$ & $100 \%$ \\
\hline Your family & $0 \%$ & $100 \%$ & $15 \%$ & $85 \%$ & $16 \%$ & $84 \%$ \\
\hline Your relative & $0 \%$ & $100 \%$ & $31 \%$ & $69 \%$ & $26 \%$ & $74 \%$ \\
\hline Your neighbor & $17 \%$ & $83 \%$ & $18 \%$ & $82 \%$ & $18 \%$ & $82 \%$ \\
\hline Your friend & $0 \%$ & $100 \%$ & $12 \%$ & $88 \%$ & $10 \%$ & $90 \%$ \\
\hline \multicolumn{7}{|c|}{ Liver cancer transmitted by } \\
\hline $\begin{array}{l}\text { Contacts or blood } \\
\text { transfusion }\end{array}$ & $83 \%$ & $17 \%$ & $43 \%$ & $57 \%$ & $50 \%$ & $50 \%$ \\
\hline $\begin{array}{l}\text { From parents to } \\
\text { offspring }\end{array}$ & $33 \%$ & $67 \%$ & $40 \%$ & $60 \%$ & $39 \%$ & $61 \%$ \\
\hline \multicolumn{7}{|c|}{ Liver cancer may be treated by } \\
\hline Medicines & $100 \%$ & $0 \%$ & $93 \%$ & $7 \%$ & $94 \%$ & $6 \%$ \\
\hline Surgery & $100 \%$ & $0 \%$ & $93 \%$ & $7 \%$ & $94 \%$ & $6 \%$ \\
\hline $\begin{array}{l}\text { Do not worry, it is } \\
\text { easily curable }\end{array}$ & $0 \%$ & $100 \%$ & $7 \%$ & $93 \%$ & $6 \%$ & $94 \%$ \\
\hline
\end{tabular}

\section{Discussion}

In the past, people were not well aware of this disease. The ratio of results among different people in Korea and other countries were different. Now a day, people in all the countries are well aware as discussed in this report about post graduate students.

\section{Conclusion}

This was concluded that the post graduate students were totally aware by this disease.

\section{References}

1. Dasanu CA (2008) Gemcitabine: vascular toxicity and prothrombotic potential. Expert Opin Drug Saf 7(6): 703-716.

2. Kubicka S, Rudolph KL, Tietze MK, Lorenz M, Manns M, et al. (2001) Phase II study of systemic gemcitabine chemotherapy for advanced unresectable hepatobiliary carcinomas. Hepato-gastroenterology 48(39): 783-789.

3. D'Costa Z, Jones K, Azad A, van Stiphout R, Lim SY, et al. (2017) Gemcitabine-induced TIMP1 attenuates therapy response and promotes tumor growth and liver metastasis in pancreatic cancer. Cancer Res 77(21): 5952-5962.

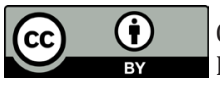

Creative Commons Attribution 4.0 International License

For possible submissions Click Here

\section{Submit Article}

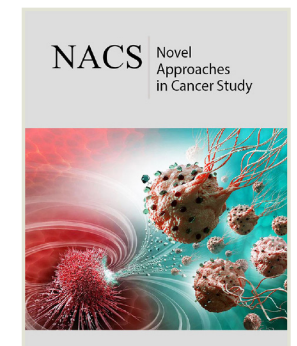

\section{Novel Approaches in Cancer Study}

Benefits of Publishing with us

- High-level peer review and editorial services

- Freely accessible online immediately upon publication

- Authors retain the copyright to their work

- Licensing it under a Creative Commons license

- Visibility through different online platforms 